\title{
МОВНА КАРТИНА СВІТУ - КОНЦЕПТУАЛЬНА КАРТИНА СВІТУ - ХУДОЖНЯ КАРТИНА СВІТУ: ПАРАМЕТРИЧНІ ОЗНАКИ Й ХАРАКТЕР СПІВВІДНОШЕННЯ
}

\author{
АНАСТАСІЯ ЯРЕМЧУК \\ Університет імені Адама Міцкевича, Познань - Польща \\ aonastykise@gmail.com; ORCID: 0000-0001-9188-2413
}

\section{JEZZYKOWY OBRAZ ŚWIATA — KONCEPTUALNY OBRAZ ŚWIATA - ARTYSTYCZNY OBRAZ ŚWIATA: CECHY PARAMETRYCZNE I CHARAKTERYSTYKA RELACJI}

\author{
ANASTAZJA JAREMCZUK \\ Uniwersytet im. Adama Mickiewicza, Poznań — Polska
}

\begin{abstract}
STRESZCZENIE. Niniejszy artykuł poświęcony jest zbadaniu zagadnienia cech parametrycznych takich pojęć jak: językowy obraz świata, konceptualny obraz świata oraz artystyczny obraz świata. Prześledzono proces kształtowania się lingwokonceptologii jako nauki niezależnej, wyznaczono znaczenie terminu lingwokonceptologia, jej obiekt oraz przedmiot, a także cel i zadania wskazanej dziedziny nauki. Wnioskujemy, że lingwokonceptologia opiera się na identyfikacji i badaniu konceptów, a także na środkach, które je reprezentują. Obraz świata to zbiór ludzkich wyobrażeń na jego temat. Konceptualne i językowe obrazy świata są ze sobą skorelowane: pierwszy obiektywizuje wiedzę w ludzkim umyśle realizowaną poprzez językowy obraz świata, przy czym jest znacznie szerszy; drugi to sposób badania pewnych indywidualnych lub narodowych osobliwości zachowań ludzkich poprzez modelowanie pojęć. Artystyczny obraz świata różni się tym, że zbudowany jest na podstawie aktualizacji obiektywnej, ale jednocześnie subiektywnej idei świata, a także ludzkiej świadomości, która graniczy z czynnikiem nieświadomym oraz iluzjami.
\end{abstract}

Słowa kluczowe: lingwokonceptologia, lingwistyka kognitywna, obraz świata, językowy obraz świata, konceptualny obraz świata, artystyczny obraz świata 


\title{
LINGUAL PICTURE OF THE WORLD - CONCEPTUAL PICTURE OF THE WORLD - ARTISTIC PICTURE OF THE WORLD: PARAMETRIC FEATURES AND CORRELATIONS
}

\author{
ANASTASIIA YAREMCHUK \\ Adam Mickiewicz University, Poznan — Poland
}

\begin{abstract}
The study elucidates a topical problem related to the manifestation of characteristic parametric features of such important concepts as the lingual picture of the world, the conceptual picture of the world, the artistic picture of the world. In the course of the investigation, the process of formation of linguoconceptology as an independent field of research is considered, the meaning of the term linguoconceptology is clarified, the object and subject of this approach along with its purpose and objectives are revealed. We conclude that linguoconceptology is based on the identification and study of concepts, as well as means that represent them. The picture of the world is a set of ideas of a person about the world. Conceptual and lingual pictures of the world are intertwined: the former objectifies knowledge in the human mind, which is accumulated through the lingual picture of the world, though it is much broader; the latter implies a means of studying certain individual or national characteristics of human behaviour through modelling concepts. The artistic picture of the world stands out as it is built on the basis of the actualisation of both objective and subjective representations of the world simultaneously, as well as on human consciousness, which borders on the unconscious and illusions.
\end{abstract}

Key words: linguoconceptology, cognitive linguistics, picture of the world, the lingual picture of the world, the conceptual picture of the world, the artistic picture of the world

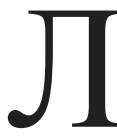

інгвоконцептологія - відносно нова наука в сучасному мовознавстві, початки якої віднаходимо в к. XX - поч. XXI ст. Думки науковців розходяться щодо походження цієї галузі, а також щодо її зв'язку з іншими науками. Зокрема, В. Іващенко зауважує, що одним 3 поштовхів для утворення галузі лінгвістичної концептології стало поширення поняття концุenm. Як напрям вона виникла в контексті функціоналізму та генеративізму на межі когнітивної та антропоцентричної наукових парадигм [див.: Іващенко 2006: 3]. Н. Долусова вважає, що лінгвоконцептологія як окрема наука первинно входила до когнітивістики (наприкінці XX ст.). Дослідник пояснює, що ця наукова дисципліна „вивчає формування та функціонування концептів, досліджує їхню структуру та зв'язки між ними на тлі мовного матеріалу, тобто шляхом дослідження безпосередньої взаємодії мови та мислення" [Долусова 2011: 72]. О. Селіванова також стверджує, що лінгвоконцептологія як наука виокремилася 3 когнітивної лінгвістики. Науковець виділяє основну мету аналізованої науки - опис концептів, а також мовних засобів, що їх репрезентують, і конкретні завдання лінгвістичної концептології [Селіва- 
нова 2008: 403]. До того ж, на думку О. Селіванової, основною категорією лінгвоконцептології $є$ концептуалізація як „один 3 процесів пізнавальної діяльності людини, що полягає в осмисленні й упорядкуванні результатів внутрішнього рефлексивного досвіду людини й уявлень про об'єкти, явища дійсності та їхні ознаки" [Селіванова 2008: 403].

Автори монографії Лінгвоконцептологія: мікроконцептосфера СВЯТКИ в украӥнському мовному просторі визначають лінгвоконцептологію як „нову лінгвістичну галузь, спрямовану на детальний аналіз концептів різних типів та їхніх мовних репрезентацій” [Космеда, Плотнікова 2010: 20], а також виділяють два основні дослідницькі підходи в межах лінгвістичної концептологіїлінгвокогнітологічний і лінгвокультурогічний [Космеда, Плотнікова 2010: 20]. У лінгвоконцептології досліджують картину світу як ,результат обробки інформації про середовище й людину. Як глобальний образ, вона являє собою основу світобачення, світовідчуття й реалізується в різноманітних формах людської поведінки, до яких належить і людська мова" [Живіцька 2010: 20]. Т. Захарова визначає картину світу як „найбільш загальне інтегральне сприйняття світу в його цілісності, сукупність знань, що формується за участі всіх рівнів і форм пізнання: теоретичного, емпіричного, логічного, чуттєвого, наукового, філософського, буденного, релігійного й міфологічного" [Захарова 2008: 118-121] (переклад автор. — А. Я.). 3. Попова та Й. Стернін картину cвimy розуміють як ,упорядковану сукупність знань про дійсність, що сформувалася в суспільній, а також груповій, індивідуальній свідомості” [Попова, Стернин 2007: 36] (переклад автор. - А. Я.).

Термін картина світу вперше, як відомо, ужив Г. Герц у працях, які присвятив вивченню фізичної картини світу. Зазначений науковець трактував цей термін як „сукупність внутрішніх образів зовнішніх предметів, 3 яких логічним шляхом можна отримувати відомості щодо поведінки цих предметів” [Герц 1959: 198] (переклад автор. - А. Я.). У роботах М. Хайдеггера термін картина світу набув такого значення: „де світ стає картиною, там до того, що існує, узагалі підходять як до того, на що націлена людина й що, відповідно, хоче піднести собі, мати перед собою [...]” [Хайдеггер 1993: 49] (переклад автор. - А. Я.).

Зауважмо, що термін картина світу виник під впливом ідей В. фон Гумбольдта та О. Потебні про внутрішню форму мови. На формування поняття “картина світу” вплинули теоретичні положення американської етнолінгвістики, зокрема гіпотеза “лінгвістичної відносності” Е. Сепіра та Б. Уорфа [див.: Живіцька 2010: 21]. Свого часу В. Гумбольдт і його послідовники вважали, що мова — , «дух народу»; вона приховує особливий світогляд і специфічний спосіб мислення. Мова, очевидно, є зовнішнім проявом духу народу. Вона створює образ, картину світу, а, отже, відмінності в мовах узгоджуються з відмінностями в поглядах на світ" [Гумбольдт 1984] (переклад автор. - А. Я.). 
Спираючись на ідеї В. фон Гумбольдта, Л. Вайсгербер розробляв теорію мовної картини світу. Зазначений дослідник уперше застосував термін картина світу в монографії Рідна мова й формування духу, у якій зазначив, що основна функція мови - формування в людини картини світу [див.: Живіцька 2010: 21]. Л. Вайсгербер надавав мові провідну роль — роль “творця світу”, при цьому навколишньому світу, довкіллю як об’ єктивному чиннику формування картини світу відводив менш важливу роль. Крім того, він припускав, що „існує відносна свобода людської свідомості від мовної картини світу, проте в їі межах" [див.: Живіцька 2010: 22].

Е. Сепір і Б. Уорф висунули відмінну за змістом теорію про те, що „мова відіграє визначну роль у процесі пізнання, а люди бачать світ по-різному крізь призму рідної мови”. Ця теорія суголосна із зазначеною вище їхньою гіпотезою лінгвістичної відносності, за якою „мова повністю переплітається 3 безпосереднім досвідом людей” [див.: Живіцька 2010: 22]. Зауважмо, що, на думку О. Хорошуна, „мова - не просто дзеркальне відображення світу, а тому фіксує не лише сприйняте, але й усвідомлюване людиною" [Хорошун 2011: 241-246].

На переконання Б. Уорфа, „ми можемо по-різному бачити і сприймати світ, але саме мова визначає спосіб нашого бачення і сприйняття довкілля" [Живіцька 2010: 23]. Учений намагався порівняти мовну та наукову картини світу, акцентуючи увагу саме на значенні мовної картини світу, що призвело до „перебільшення значення мови для розвитку науки” [Живіцька 2010: 23]. Розвиваючи теорію В. Гумбольдта, О. Потебня запропонував власну філософію мови, зосереджуючи увагу на ролі слова та доводячи, що саме слово $\epsilon$ засобом сприйняття думки. Сучасний український мовознавець В. Жайворонок висунув „концепцію інтерпретації лінгвофілософської категорії «мовна картина світу»” [Живіцька 2010: 23-24]. Цей учений уважає, що „всесвіт $\epsilon$ предметом пізнання, тому, осмислюючи його, людина пізнає й саму себе" [Живіцька 2010: 23-24]. Одним 3 найважливіших елементів цього пізнання $\epsilon$, звісно, мова.

Лінгвісти традиційно виділяють концептуальну та мовну картини світу. Концептуальна картина світу містить інформацію, репрезентовану в поняттях, „У той час як в основі мовної моделі лежать знання, закріплені в семантичних категоріях і семантичних полях, складених зі слів і словосполучень” [Хорошун 2011: 241-246]. Концептуальна картина світу відображає структуру репрезентації знання. Хоча зміст понять “концептуальна картина світу” та "мовна картина світу" є цілком різним, відмінності між ними досить умовні, оскільки між зазначеними картинами світу відстежуємо зв'язок, як між мисленням і мовою.

На думку О. Хорошуна, „концептуальна картина світу — це базис картини світу як ядро світогляду, що репрезентує риси специфічного людського спо- 
собу світосприйняття. ККС містить узагальнену інформацію про світ, вона ширша й багатша, ніж МКС. За межами ККС залишається інформація, що становить особливості мовного сприйняття дійсності в тому чи тому мовному середовищі й відображається в мовній культурі народу. ККС містить інформацію в поняттях, а МКС виявляє знання, закріплені в значеннях слів і словосполучень" [Хорошун 2011: 241-246] чи інших мовних формах. Як уважає О. Хрищена, „концептуальна картина світу — це не лише система понять про сукупність реалій довкілля, а й система смислів, утілена в ці реалії через слова - концепти. Концептуальна картина світу є значно ширшою, ніж мовна, тому що в іiі створенні беруть участь різні типи мислення" [див. Хрищена 2012]. У праці Ж. Маслової концептуальна картина світу пояснена як ,,той ментальний рівень або та ментальна (психічна) організація, де зосереджена сукупність усіх концептів, даних розуму людини, їх неупорядковане об'єднання” [Маслова 2012: 14] (переклад автор. - А. Я.).

Мовна картина світу — це „відбитий засобами мови образ свідомості, реальності, модель інтегрального знання про концептуальну систему уявлень, що репрезентована мовою. МКС прийнято відмежовувати від концептуальної, або когнітивної моделі світу, що є основою мовного втілення, словесної концептуалізації сукупності знань людини про світ” [Хорошун 2011: 241-246]. О. Хрищена подає своє визначення мовної картини світу, відповідно до якого це ,система взаємопов’язаних мовних одиниць, що відбиває об' єктивний стан речей довкілля і внутрішнього світу людини. Якщо концептуальна картина світу існує у вигляді концептів, що утворюють концептосферу, то мовна картина світу існує у вигляді значень мовних знаків, які утворюють сукупний семантичний простір мови" [Хрищена 2012]. 3. Попова та Й.Стернін тлумачать МКС як ,сукупність зафіксованих в одиницях мови уявлень народу про дійсність на певному етапі розвитку народу, уявлення про дійсність, відображене в мовних знаках і їхніх значеннях, - мовне членування світу, мовне упорядкування предметів і явищ, що закладені в системних значеннях слів, інформація про світ" [Попова, Стернин 2007: 38] (переклад автор. - А. Я.).

На переконання О. Хрищеної, концептуальна картина світу здатна накладатися на мовну через засоби мови. Також ця дослідниця вказує, що основу зазначених картин світу формують різні засоби: ККС виражається через поняття та уявлення, а МКС — через мовні одиниці. Принциповою відмінністю між ними $\epsilon$,наявність невербальних засобів вираження в концептуальній картині світу й лінгвістичних засобів творення загальних рис та національних особливостей мовної картини світу” [Хрищена 2012]. Утім, 3 іншого боку, когнітивна та мовна картини світу пов'язані між собою як „первинне та вторинне, як ментальне явище та його вербальне озовнішнення, як зміст свідомості та засіб доступу дослідника до цього змісту" [Попова, Стернин 2007: 39] (переклад автор. - А. Я.). 
У лінгвістиці виокремлюють і художню картину світу, що є вторинною картиною світу, ознаки якої збігаються 3 характеристиками мовної. „Вона виникає у свідомості читача під час сприйняття ним художнього твору (або у свідомості глядача, слухача - під час сприйняття інших витворів мистецтва)" [Попова, Стернин 2007: 40]. 3. Попова та Й. Стернін підкреслюють, що в художньому тексті картина світу створюється через відповідні мовні засоби. Вона має здатність „відображати індивідуальну картину світу у свідомості письменника. У художній картині світу можуть бути виявлені концепти, притаманні сприйняттю світу тільки конкретного автора - індивідуальні концепти письменника. Отже, мова $є$ засобом створення вторинної художньої картини світу, що відображає картину світу творця художнього витвору” [Попова, Стернин 2007: 40] (переклад автор. - А. Я.). Чіткий розподіл у мові структур прозаїчних і поетичних текстів сприяв виокремленню з художньої картини світу поетичної картини світу [Маслова 2012: 30].

О. Тупиця пропонує грунтовне визначення поняття “поетична картина світу” — це „сукупність загальних рис, що властиві внутрішнім індивідуальним моделям світу; вона створюється в тексті за допомогою системи образів, типових мотивів, ключових лексем; це поєднання об'єктивних і суб'єктивних уявлень про світ" [Тупиця 2009: 98]. За спостереженнями Ж. Маслової, поетична картина світу, як і ККС, передусім „структурує мовну репрезентацію творчих і несвідомих процесів [Маслова 2012: 45]. Зазначена дослідниця вважає, що концептуальна система естетично значуща й „структурує творчу діяльність індивіда на створення та інтерпретацію альтернативної поетичної реальності, що характеризується суб' єктивністю, емоційною домінантою, я-центричністю, фрагментарністю" [Маслова 2012: 45] (переклад автор. - А. Я.). Крім того, Ж. Маслова звертає увагу на те, що основною когнітивною функцією поетичної картини світу $є$ „вироблення можливості орієнтації в суб'єктивній реальності, приведення систем “ $Я$ ” ' “СВIT” у рівновагу. Предметом знань цієї картини $\epsilon$ естетично усвідомлюване суб'єктивне бачення екзистенціальних й емоційних ситуацій. А основними структурними елементами поетичної картини світу $\epsilon$ художні (поетичні) концепти” [Маслова 2012: 52] (переклад автор. - А. Я.).

Отже, доходимо висновку, що лінгвоконцептологія грунтується на виявленні та вивченні концептів, а також засобів їхньої репрезентації. Картина світу — це сукупність уявлень людини про світ, концептуальна та мовна картини світу взаємопов'язані між собою: перша - об'єктивує знання у свідомості людини, що реалізується через мовну картину світу, але вона значно ширша; друга - засіб вивчення певних індивідуальних чи національних особливостей поведінки людей через моделювання концептів. Художня картина світу різниться тим, що вибудовується на основі актуалізації об'єктивного та водночас суб' єктивного уявлення про світ, а також на людському свідомому, що межує з несвідомим та ілюзіями. 


\section{Список використаної літератури}

Герц Г., Принципы механики, изложенные в новой связи, [в:] Жизнь науки: Антология вступлений к классике естествознания, Москва: Изд-во АН СССР, 1959, с. 206-210.

Гумбольдт В. фон, Избранные труды по языкознанию, Москва: Прогресс, 1984.

Долусова Н. В., Концепт телефонний дзвінок та його вербалізація в жіночих текстах (на матеріалі оповідань Д. Паркер), [в:] „Сучасні тенденції розвитку мов”, 2011, № 6, c. 72-75.

Живіцька І. А., Мовна картина світу як відображення реальності, [в:] „Філологічні студіï’, 2010, № 4, с. 20-25.

Захарова Т. В., Термин картина мира в современных лингвистических исследованиях, [в:] Слово, высказывание, текст в когнитивном, прагматическом и культурологическом acnектаx, Челябинск: ООО „Изд-во Рекпол”, 2008, с. 118-121.

Іващенко В. Л., Концептуальна репрезентація фрагментів знання в науково-мистецькій картині світу (на матеріалі української мистеитвознавчоїтермінології), Київ: Вид. дім Дмитра Бураго, 2006.

Космеда Т. А., Плотнікова Н. В., Лінгвоконщептологія: мікроконцептосфера СВЯТКИ в украӥнському мовному просторі, Львів: Коло, 2010.

Маслова Ж. Н., Когнитивная концепция поэтической картины мира, Москва: Флинта, 2012.

Попова 3. Д., Стернин И. А., Семантико-когнитивный анализ языка, Воронеж: Истоки, 2007.

Селіванова О. О., Сучасна лінгвістика: напрями та проблеми, Полтава: Довкілля-К, 2008.

Тупиця О., Особливості організації поетичної картини світу, [в:] „Філологічні науки”, 2009, вип. 1, с. 98-104.

Хайдеггер М., Время и бытие, Москва: Республика, 1993.

Хорошун О. О., Мовна та концептуальна картини світу в дослідженнях сучасної лінгвістичної науки, [в:] Глухівські наукові читання-2011, матер. міжнарод. наук.практ. конф. (15-17 лист. 2011 року), Глухів: РВВ ГНПУ ім. О. Довженка, 2011, c. 241-246.

Хрищена О., Поняття мовної та концептуальної картин світу у науці про мову, [в:] Електронний ресурс: https://naub.oa.edu.ua/2012/ponyattya-movnoji-ta-kontseptualnojikartyn-svitu-u-nautsi-pro-movu/ (26. 05. 2012).

\section{Spysok vykorystanoi literatury [References]}

Gercz G., Printsipy mexaniki, izlozhennye vnovoj svyazi [The Principles of Mechanics Presented in a New Form], [v:] Zhizn' nauky: Antologiya vstuplenij k klassike estestvoznaniya, Moskva: Izd-vo AN SSSR, 1959, s. 206-210.

Gumbol'dt V.fon, Izbrannye trudy po yazykoznaniyu [Selected Works on Linguistics], Moskva: Progress, 1984. 
Dolusova N. V., Kontsept telefonnyi dzvinok ta yoho verbalizatsiia $v$ zhinochykh tekstakh (na materiali opovidan D. Parker) [The Concept of a Phone Call and Its Verbalization in Women’s Texts], [v:] „Suchasni tendentsii rozvytku mov”, 2011, № 6, s. 72-75.

Zhyvitska I. A., Movna kartyna svitu yak vidobrazhennia realnosti [The Language Picture of the World as a Reflection of Reality], [v:] ,Filolohichni studii”, 2010, № 4, s. 20-25.

Zaxarova T. V., Termin kartina mira $v$ sovremennyx lingvisticheskix issledovaniyax [The Term Worldview in Modern Linguistic Research], [v:] Slovo, vyskazyvanie, tekst $v$ kognitivnom, pragmaticheskom i kul'turologicheskom aspektax, Chelyabinsk: OOO „Izd-vo Rekpol”, 2008, s. 118-121.

Ivashchenko V. L., Kontseptualna reprezentatsiia frahmentiv znannia v naukovo-mystetskii kartyni svitu (na materiali ukrainskoi mystetstvoznavchoi terminolohii) [Conceptual Representation of Knowledge Fragments in the Scientific and Artistic Picture of the World (Based on the Material of Ukrainian Art Criticism Terminology)], Kyiv: Vyd. dim Dmytra Buraho, 2006.

Kosmeda T. A., Plotnikova N. V., Linhvokontseptolohiia: mikrokontseptosfera SVIATKY vukrainskomu movnomu prostori [Linguistic Conceptology: Microconcept Sphere SVIATKY in Ukrainian Language Space], Lviv: Kolo, 2010.

Maslova Zh. N., Kognitivnaya konceptsiya poe'ticheskoj kartiny mira [The Cognitive Concept of Poetic Picture of the World], Moskva: Flinta, 2012.

Popova Z. D., Sternin I. A., Semantiko-kognitivnyj analiz yazyka [Semantic and Cognitive Analysis of the Language], Voronezh: Istoki, 2007.

Selivanova O. O., Suchasna linhvistyka: napriamy ta problemy [Modern Linguistics: Directions and Problems], Poltava: Dovkillia-K, 2008.'

Tupytsia O., Osoblyvosti orhanizatsii poetychnoi kartyny svitu [Features of the Organizations of the Poetic Picture of the World], [v:] „Filolohichni nauky”, 2009, vyp. 1, s. 98-104.

Xajdegger M., Vremya i bytie [Time and Being], Moskva: Respublika, 1993.

Khoroshun O. O., Movna ta kontseptualna kartyny svitu $v$ doslidzhenniakh suchasnoi linhvistychnoi nauky [Linguistic and Conceptual Pictures of the World in Modern Scientific Linguistic Studies], [v:] Hlukhivski naukovi chytannia-2011, mater. mizhnarod. nauk.-prakt. konf. (15-17 lyst. 2011 roku), Hlukhiv: RVV HNPU im. O. Dovzhenka, 2011, s. 241-246.

Khryshchena O., Poniattia movnoi ta kontseptualnoi kartyn svitu v nautsi pro movu [The Notions of Linguistic and Conceptual Pictures of the World in the Science of Language], [v:] Elektronnyiresurs: https://naub.oa.edu.ua/2012/ponyattya-movnoji-takontseptualnojikartyn-svitu-u-nautsi-pro-movu/ (26. 05. 2012). 